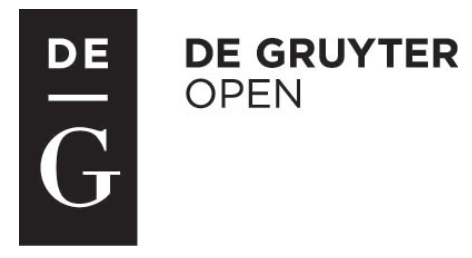

Przedsiębiorczość i Zarządzanie Entrepreneurship and Management University of Social Sciences Publishing House

ISSN 1733-2486

Volume XV, Issue 2, pp. 75-90 DOI 10.2478/eam-2014-0018

\title{
Łukasz Arendt
}

University of Lodz

\section{New system of employment forecasting in Poland}

Abstract: The goal of the paper was to describe the system of employment forecasting in Poland and to present forecasts results. The paper described the main assumptions and elements of the system of employment forecasting (the structure of econometric models and on-line forecasting tool). It also elaborated on employment forecasts at national, regional and occupational levels. The analysis of forecasts enabled drawing some conclusions, important from the point of view of the perspectives of the Polish labour market and the labour market policy.

Key words: employment forecasting, occupations, econometric modelling, Polish labour market, regional disparities.

\section{Introduction}

Demographic forecasts for Poland clearly indicate that two negative trends, from the point of view of labour market, will take place - first, the decline in the total number of population (by 2035 it will decrease, as compared to 2007, by $5.6 \%$ ), and second, the processes of rapid aging of population. According to the forecasts by the Polish Central Statistical Office, there is no doubt that by 2035 we will witness a significant loss of working-age population (projected at 3.8 million people), with simultaneous increase of share of people in no-mobile age in the working age population (from $37.8 \%$ in 2007 to $47.2 \%$ in 2035) [CSO 2009] $]^{6}$.

\footnotetext{
${ }^{6}$ Similar conclusions stem from predictions based on the SYSDEM 2.0 model, described in detail in [Bukowski (ed.) 2010]. The population of people in non-mobile age is defined as those aged 45-59 years for women and 45-64 for men (age range in this definition will probably change as a result of retirement age raise in Poland, that is to be 67 years for men in 2020, and the same for women in 2040). This group is characterised by a low propensity for occupational, education and spatial mobility, which results in lower employability on the rapidly changing labour market.
} 
Demographic forecasts point out that in the long run labour force in Poland will decrease. So, important issue connected with this fact is how it influences labour market equilibrium - if unemployment rate will decrease, increase, or stabilize at some level; in which occupations it will be easy to find a job, and in which occupations finding a job will be extremely hard? To address this issue, it is necessary to have forecasts of developments of the demand side of the labour market. Although the system of forecasting labour demand is, in many EU countries, an important element of the institutional framework and is used as instrument to promote socio-economic policies (in particular, labour market policies), in Poland, such a system have not yet existed, although attempts to create it had already been taken.

Setting up a system for forecasting labour demand in Poland is a challenge but, at the same time, a necessity. The concept of introducing such a system was initiated in 2011 by launching a Task Establishing the integrated forecasting and information system providing employment forecasts within an EU funded project Analysis of the processes on the Polish labour market and in the area of social integration in the context of conducted economic policy. The project conducted by the Human Resource Development Centre (Leader) and the Institute of Labour and Social Studies (Partner) has aimed to implement an integrated system of employment forecasting in Poland by 2014. Although it is not yet a system that forecasts labour demand, it should be seen as a milestone in setting up this kind of measure in the coming years.

Comparison of demographic projections (labour supply) with forecasts of labour demand (in different cross-sections) enables to determine the scale and nature of the imbalance on the labour market in the future, identifying those areas (such as groups of occupations, the types of skills and knowledge) in which there will be excess supply of labour (resulting in unemployment) or labour supply shortages?. On this basis, policy makers will be able to take reasonable steps in order to reduce the scale of these imbalances. The labour market and education policy (in Poland, active labour market policies and system of lifelong learning are the two most important pillars of flexicurity) with the use of specific tools can help to "transfer" labour surplus to areas of labour shortages. Labour demand forecasts should also allow to take informed decisions on migration policy, in a situation where balancing the labour market through the national labour force may be impossible. It is clearly seen, that creation of the system of forecasting labour demand is essential to cope with the challenges faced by Poland in the near future. This argument has been strengthened by research studies results showing that the lack of medium and long-term labour

\footnotetext{
${ }_{7}$ The problem of skills mismatch at European Union level has been raised in particular in the framework of the initiative New skills for new jobs [see New Skills for New Jobs, 2008]. It should also be noted that to achieve the employment goals defined in the strategy Europe 2020, it is necessary to keep people in non-mobile age economically active as long as possible. It requires, in many cases, adaptation of the competences (and sometimes full re-training) of these people to the employers' needs - here the role of the system of forecasting labour demand is undeniable.
} 
demand forecasts by regions and professions cannot be compensated for even the best system of on-going monitoring of deficit and surplus professions carried out by labour offices [Kryńska (ed.) 2007, p. 230].

The goal of the paper is to describe the system of employment forecasting in Poland and to present forecasts results for Poland, Polish regions and selected minor occupational groups. These forecasts results enable to verify the research hypothesis saying that Polish labour market will follow the trend of structural change favouring highly-skilled labour force and growing labour market polarisation [see Acemoglu and Autor 2011, pp. 1070-1096].

\section{New system of employment forecasting in Poland}

It has been assumed that a new Polish system of employment forecasting should be based on foreign expertise and learn as much as possible from the experience of other EU Member States that have been developing their forecasting system for many years. Basically, we would like to take advantage of a leapfrog opportunity by implementing up-to-date developments in econometric modelling and management of the forecasting process, including methods of making the results available to the public ${ }^{8}$.

The general recommendations stemming from analysed best EU practices are following [Arendt, Ulrichs (eds.) 2010, p. 8]:

- Setting up a well-organised forecasting system is a process that takes time and requires substantial investment;

- The issues common to all forecasting systems are data availability and inconsistency of time series caused by changes in statistical classifications;

- Although it is impossible to predict future (all forecasts are imperfect), the quality of forecasts should be evaluated in terms of their usefulness to different stakeholders;

- The most successful forecast is the one that addresses and influences specific target groups (especially policy makers) to undertake specific measures in order to avoid projected negative changes. In this sense, we should wish that forecasts will 'destroy themselves';

- To forecast demand for labour it is necessary to include in the model different types of demand, such as expansion demand and replacement demand in order to make projection on the number of job openings;

- As some international experiences show, the major impact on the labour market up to 2020 is expected to be related to changes in replacement demand, while expansion demand is projected to be rather moderate;

\footnotetext{
${ }^{8}$ Description of systems of forecasting labour demand in EU and non-EU contries are available in: [Heijke (ed), 1994], [Neugart, Schomann (eds) 2002], [CEDEFOP 2009], [Helmrich, Zika (eds) 2010], [ROA 2011], [CEDEFOP 2012], [Arendt, Ulrichs (eds) 2010], [Capellen, Gjefsen, Gjelsvik, Holm, Stolen 2013].
} 
- Well-established systems of forecasting demand for labour should be based on an integrated approach in which demand and supply-side of the labour market are modelled within one framework.

Those recommendations, as well as specific measures, were taken into account while creating a new Polish system of employment forecasting, that is based on the following characteristics:

- the core of the system are the econometric models - the results generated by these models are subject to revision by experts, and only the adjusted forecasts are entered into the forecasting system,

- the forecast horizon is 2020 ,

- forecasts are generated in three cross-sections:

- the occupational groups, according to the Polish Classification of Occupations and Specializations for the labour market needs $2010^{9}$ at the level of minor groups (three-digit codes),

- economic sectors (according PKD2007 ${ }^{10}$ broken down into: agriculture, industry, market services and non-market services),

- the NUTS II statistical areas,

- the main recipient of the forecasts are public employment services. Forecasts are intended to provide a reference point for labour market policy at the national, regional and even local level ${ }^{11}$.

\footnotetext{
${ }^{9}$ This Polish classification is coherent and comparable with ISCO-08 classification.

${ }^{10}$ The Polish Classification of Activities (PKD2007) is coherent and comparable with the clarification NACE Revision 2.

${ }^{11}$ However, the on-line forecasting tool is supposed to be used by the young people who are about to decide what career path to choose, and other groups of stakeholders who should also benefit from it (i.e. labour market institutions, educational institutions, employers, employees, etc.).
} 


\section{Figure 1. Screenshot of the on-line forecasting tool*}

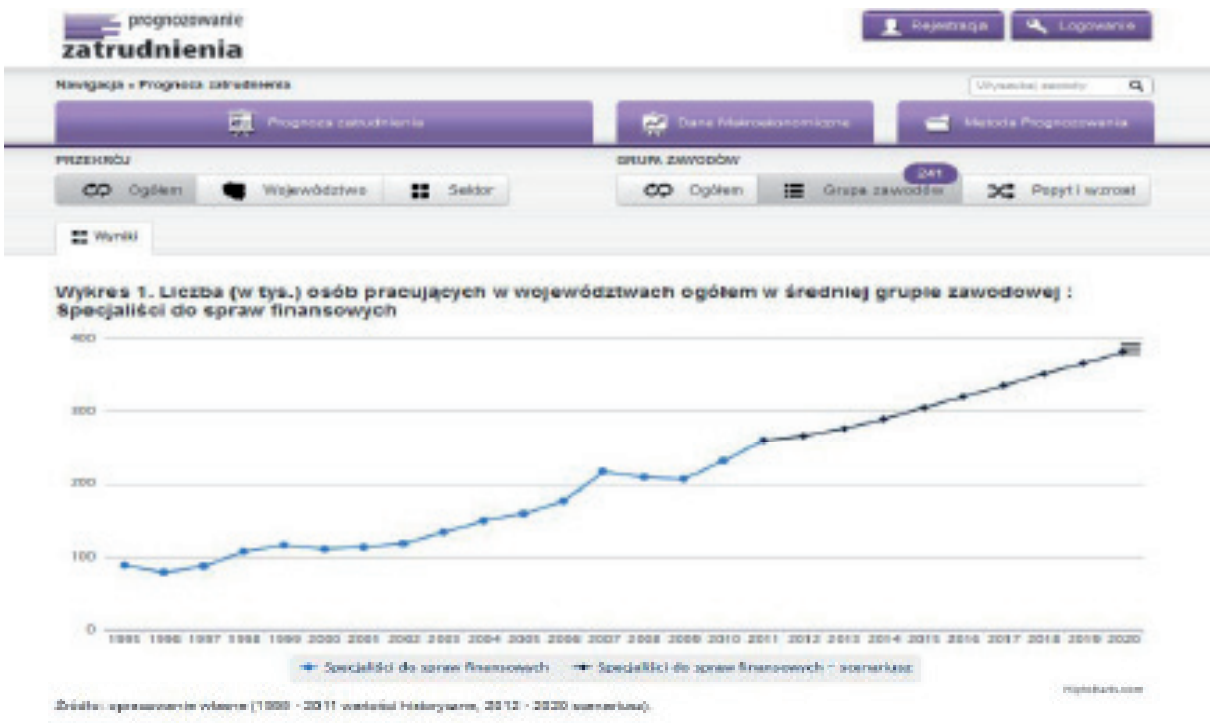

Source: www.prognozowaniezatrudnienia.pl.

* The screenshot shows the forecast for the minor occupational group 241 (Finance professionals) for Poland.

The system of employment forecasting consists of two main elements:

- infrastructure of the econometric models which generate employment forecast, and

- on-line forecasting tool that provides a graphical interface through which the user of the system will be able to download the results of the forecasts. Forecasting tool (in Polish) is available on the website www. prognozowaniezatrudnienia.pl (Figure 1).

The forecasting methodology is built on models of the demand side of the labour market, with the control from the supply side (population, labour force participation). The flexibility of econometric models is provided by their hierarchical structure and the possibility of expert adjustments at each stage of modelling and forecasting.

Employment forecasts at the national level are developed through the use of a hierarchical approach to econometric modelling, with ensuring consistency of the forecasts at every level of disaggregation (for each cross-section) (see Figure 2). 
Figure 2. Structure of the econometric forecasting model

\begin{tabular}{|c|c|}
\hline $\begin{array}{l}\text { (A) Macro model-total } \\
\text { employment }\end{array}$ & $\begin{array}{l}\text { del-total } \\
\text { nent }\end{array}$ \\
\hline $\begin{array}{l}\text { (B) Regional model - } \\
\text { employment by voivodeships } \\
\text { (16) }\end{array}$ & $\begin{array}{l}\text { (C) Sectoral model - } \\
\text { employment by economic } \\
\text { sectors (4) }\end{array}$ \\
\hline \multicolumn{2}{|c|}{$\begin{array}{l}\text { (D) Occupational model-employment by major occupational groups } \\
\text { (10) }\end{array}$} \\
\hline \multicolumn{2}{|c|}{$\begin{array}{l}\text { Forecast - employment by major (10), sub-major (43) and minor (133) } \\
\text { occupational groups }\end{array}$} \\
\hline $\begin{array}{l}\text { Forecast - employment by } \\
\text { major (10), sub-major ( } 43 \text { ) and } \\
\text { minor (133) occupational } \\
\text { groups by volvodeships }\end{array}$ & $\begin{array}{c}\text { Forecast - employment by major } \\
(10) \text {, sub-major ( } 43 \text { ) and minor } \\
\text { (133) occupational groups by } \\
\text { sectors }\end{array}$ \\
\hline
\end{tabular}

Source: Kwiatkowski et. al. 2001, p. 76.

Global (POLMOD 2013) model (A), which is a multi-equation econometric model, generates an overall employment forecast. The model consists of two sub-models: macroeconomic model and model of the labour market. The macro-model takes into account interactions among incomes, consumption, capital accumulation, investments, export, import, added value and yields GDP and final domestic demand values. The sub-model of labour market is based on 5 stochastic equations (number of employees, number of workers, average wage, number of unemployed, number of job offers) and 4 identity equations. Interactions in the sub-model of labour market are presented on the Figure 3. 
Figure 3. Interactions in the sub-model of labour market

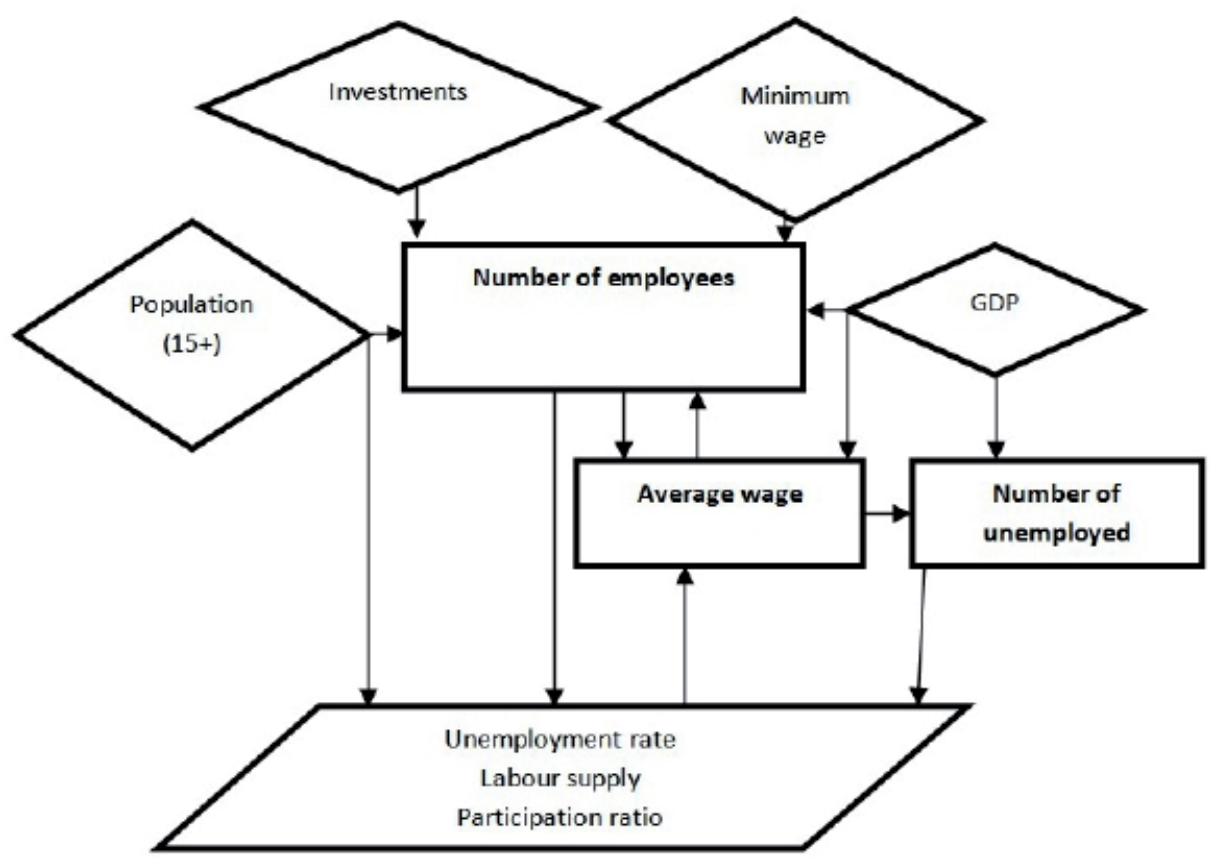

Source: . Arendt, A. Gajdos, Labour demand forecasting in Poland - a new approach, presentation on the Conference Long-term labour market forecasting in Europe, Nuremberg 24-25 October 2013.

Global model by regions (B) (that includes spatial interactions) and a global model by sectors (C) (multi-equation panel data model) allow to forecast independently the number of employees at, respectively, spatial and sectoral level, taking into account the forecasts from the global model (A). Regional model (B) is a multi-equation recurrence model that estimates (using SUR methodology) GDP in each region and then, with the use of Seemingly Unrelated Regression Equations system with spatial interactions, yields employment number in a given region. The sectoral model (C) is based on modified CobbDouglas production function - it consists of long-run employment functions for a given economic sector. The total number of employees in a given region or economic sector is then split by the occupational (cause and effect model) model (D) into major, sub-major and minor occupational group ${ }^{12}$.

${ }^{12}$ The new approach to forecasting employment in Poland is consistent with the modern labour market forecasting systems existing in developed economies (see e.g.). All of those systems are based on macro-modelling framework combined with labour market sub-models which generate employment 


\section{Employment perspectives in Poland to 2020}

The analysis of employment forecasts generated by the system shows that at the aggregated level, changes in the employment numbers will be moderate. However, significant differences in the development paths are noticeable by regions, and, especially, by occupational groups.

By 2020 Poland should witness a slight decrease in employment - employment will fall between 2012 and 2020 by $0.32 \%$, from 15636 ths to 15587.7 ths people.

\section{Figure 3. Employment in Poland - forecast 2012-2020}

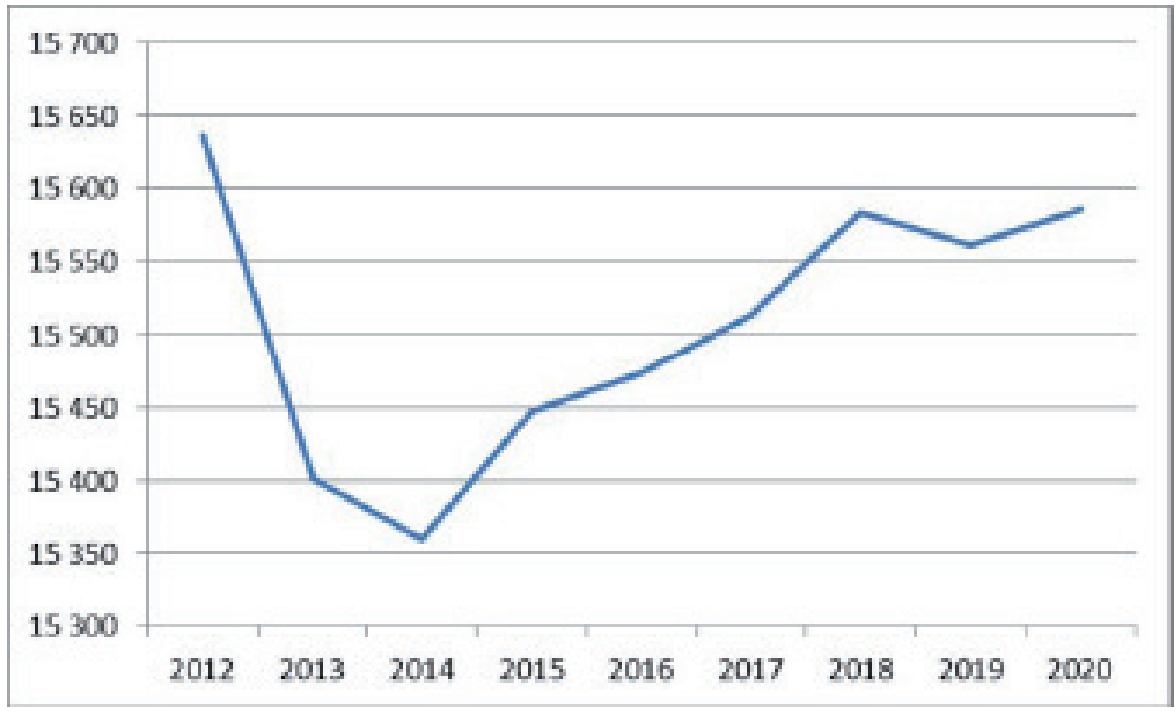

\section{Source: forecast results database.}

However, as presented in Figure 3, Polish economy will suffer from a sharp decline of employment between 2012 and 2014, which may be attributed to the long-lasting effects of the world economic crisis that began in 2008 in the U.S. It is predicted that from 2015 to 2018 employment will recover, followed then by slight changes and stabilisation till 2020.

This fall in employment will be distributed unevenly between regions. In eight Polish regions the number of employees should rise:

- in Dolnoslaskie region by 4.2\% (from 1092.9 ths in 2012 to 1138.7 ths people in 2020);

forecasts at occupational, regional and sectoral level. However, it should be stated that Polish system of labour market forecasting should be continuously developed in order to introduce such features, that already exist in other countries, as forecasting expansion demand (see e.g. [Cörvers, Dupuy 2010], replacement demand (see e.g. [Fox, Cornerford 2008]), analysis of future labour demand by educational level (see e.g. [Wilson 2013]), by age groups (see e.g. [Hyndman, Booth 2008]), and integration of demand and supply-side of the labour market within one modelling framework. 
- in Pomorskie region also by 4.2\% (from 929.9 ths in 2012 to 968.7 ths people in 2020);

- in Slaskie region by 3.9 \% (from 1912.9 ths in 2012 to 1986.6 ths people in 2020);

- in Mazowieckie region by 3.3\% (from 2426.8 ths in 2012 to 2505.7 ths people in 2020);

- in Lubelskie region by $3.1 \%$ (from 923.9 ths in 2012 to 952.2 ths persons in 2020);

- in Swiętokrzyskie region by $2.2 \%$ (from 569 ths in 2012 to 581.7 ths people in 2020);

- in Warmia and Mazury region by 2.1\% (from 515 in 2012 to 525.8 ths persons in 2020);

- in Wielkopolskie region by $0.5 \%$ (from 1361.9 ths in 2012 to 1369.4 persons in 2020).

At the same time, the number of employees should decline in other eight Polish regions:

- in Lubuskie region by $13.5 \%$ (from 410 ths in 2012 to 354.6 ths persons in 2020);

- in Podlaskie region by $13.1 \%$ (from 458 ths in 2012 to 397.9 ths persons in 2020);

- in Opolskie region by 7.9\% (from 355 ths in 2012 to 326.8 ths persons in 2020);

- in Zachodniopomorskie region also by 7.9\% (from 574 ths in 2012 to 528.5 ths people in 2020);

- in Podkarpackie region by $4.9 \%$ (from 809.9 ths in 2012 to 769.9 ths persons in 2020);

- in Kujawsko-pomorskie region by 4.8\% (from 778 ths in 2012 to 740.6 ths people in 2020);

- in Malopolskie region by 4.7\% (from 1310.9 ths in 2012 to 1249.3 ths persons in 2020);

- in Lodzkie region by $1.5 \%$ (from 1207.9 ths in 2012 to 1189.3 ths people in 2020).

The data shows that the huge gap will arise between best performing regions (eg Dolnoslaskie and Pomorskie) which will strengthen their competitive advantages, and worst performing regions (eg. Lubuskie and Podlaskie), in which situation on the labour market is going to deteriorate.

From the point of view of labour market, as well as lifelong learning policies, it is important to foresee the directions and scale of changes in the em- 
ployment levels by occupational groups. Having this knowledge, policy makers and institutions responsible for conducting these policies, may programme and undertake steps aiming at balancing the labour market in the future. This information is also important for young people, because it helps in taking educational choices that would maximise the youth employability at the end of their educational path.

Hence, in this section of the paper we will analyse the forecast results in order to point occupational groups with highest dynamics (as for increase and decline) between 2012 and 2020, and groups with highest and lowest employment level in 2020.

The biggest increase in labour demand should take place in the $2^{\text {nd }}$ major group "Professionals" (see Table 1). Analysis of data confirms the international trends related to development of information society and growing importance of Information and Communication Technologies for economy's performance - the biggest rise in number of employees (by almost 60\%!!!) is forecasted in the minor group of professionals employed in IT branch - exactly the software and applications developers and analysts as well as database and network professionals (Table 1).

\section{Table 1. 10 minor occupational groups with highest increase in employ- ment (in ths)}

\begin{tabular}{|c|c|c|c|c|c|c|c|c|c|c|}
\hline \multirow{2}{*}{ Minor group } & \multicolumn{9}{|c|}{ Ycar } & \multirow{2}{*}{$\begin{array}{l}\text { Increase } \\
\text { (in } \% \text { ) }\end{array}$} \\
\hline & 2012 & 2013 & 2014 & 2015 & 2016 & 2017 & 2018 & 2019 & 2020 & \\
\hline $\begin{array}{l}\text { Software and applications } \\
\text { developers and analysts; } \\
\text { Databax and network } \\
\text { professionals }\end{array}$ & 181.8 & 191.7 & 203.7 & 217.7 & 231.1 & 244.9 & 259.3 & 272.4 & 286.3 & 57.5 \\
\hline $\begin{array}{l}\text { Administration } \\
\text { professionals; Sales, } \\
\text { markering and public } \\
\text { relacions professionals }\end{array}$ & 389.4 & 405.1 & 425.2 & 449.3 & 472.0 & 495.3 & 519.8 & 541.5 & 564.8 & 45.1 \\
\hline Finance professionals & 265.9 & 276.0 & 289.2 & 305.0 & 319.9 & 335.2 & 351.3 & 365.5 & 380.7 & 43.2 \\
\hline $\begin{array}{l}\text { Physical and earth science } \\
\text { professionals; } \\
\text { Mathematicians, actuaries } \\
\text { and statiscicians }\end{array}$ & 23.5 & 24.4 & 25.5 & 26.8 & 28.1 & 29.4 & 30.7 & 31.9 & 33.2 & 41.2 \\
\hline $\begin{array}{l}\text { Vocational education } \\
\text { teachers }\end{array}$ & 21.1 & 21.8 & 22.7 & 23.8 & 24.9 & 25.9 & 27.1 & 28.0 & 29.1 & 37.5 \\
\hline Electrotechnology enginecrs & 54.2 & 55.8 & 58.0 & 60.7 & 63.2 & 65.8 & 68.5 & 70.8 & 73.4 & 35.4 \\
\hline $\begin{array}{l}\text { Social and religious } \\
\text { professionals }\end{array}$ & 80.4 & 82.6 & 85.7 & 89.6 & 93.1 & 96.8 & 100.6 & 103.9 & 107.5 & 33.6 \\
\hline Life science professionals & 46.4 & 47.6 & 49.3 & 51.5 & 53.5 & 55.5 & 57.7 & 59.5 & 61.6 & 32.7 \\
\hline $\begin{array}{l}\text { Enginecring professionals } \\
\text { (excluding } \\
\text { electrotechnology) }\end{array}$ & 197.3 & 202.3 & 209.5 & 218.6 & 226.9 & 235.4 & 244.4 & 252.1 & 260.4 & 32.0 \\
\hline $\begin{array}{l}\text { Architects, planners, } \\
\text { surveyors and designers }\end{array}$ & 91.5 & 93.7 & 97.0 & 101.0 & 104.8 & 108.6 & 112.6 & 116.1 & 119.8 & 30.9 \\
\hline
\end{tabular}

Source: forecast results. 
High increases are also reported in occupations that require technical knowledge and education (e.g. physical and earth science professionals, mathematicians, actuaries and statisticians, engineering professionals, electro-technology engineers, architects, planners, surveyors and designers). Growing importance of specific vocational skills, instead of universal skills, is confirmed by relatively high raise in number of vocational education teachers on the labour market in 2020. Financial knowledge and managerial skills also seem to be in a high demand.

The biggest decrease of labour demand is concentrated within two major occupational groups: skilled agricultural, forestry and fishery workers, and craft and related trades workers (see Table 2). These results reaffirm two phenomena. The first phenomenon is connected with the fact that changes in the sectoral structure of the Polish economy have led to decline of the role of agriculture and growing importance of services and manufacturing sectors. This, in turn, affects the employment structure, which is going to be more and more modern - that means higher employment in service sector and shrinking number of employees in agriculture. The other phenomenon is related to skillbiased technological change that favours highly skilled professionals - technology is replacing human resources in simple operations that may be automated. Thus, demand for low-skilled employees performing simple tasks is going to fall by 2020, which is clearly seen in Table 2 .

\section{Table 2. 10 minor occupational groups with highest decrease in employ- ment (in ths)}

\begin{tabular}{|l|c|c|c|c|c|c|c|c|c|c|}
\hline \multirow{2}{*}{ Minor group } & \multicolumn{7}{|c|}{ Year } & $\begin{array}{c}\text { Decrea } \\
\text { se (in } \\
\%)\end{array}$ \\
\cline { 2 - 11 } & 2012 & 2013 & 2014 & 2015 & 2016 & 2017 & 2018 & 2019 & 2020 & 22.6 \\
\hline Other elementary workers & 97.1 & 93.0 & 90.1 & 87.8 & 85.2 & 82.7 & 80.4 & 77.7 & 75.2 & 23 \\
\hline $\begin{array}{l}\text { Wood treaters, cabinet- } \\
\text { makers and related trades } \\
\text { workers }\end{array}$ & 152.2 & 141.4 & 134.8 & 130.8 & 124.8 & 123.0 & 121.8 & 118.8 & 116.7 & 23.3 \\
\hline $\begin{array}{l}\text { Machinery mechanics and } \\
\text { repairers }\end{array}$ & 216.4 & 203.8 & 196.9 & 193.8 & 187.7 & 181.8 & 176.7 & 169.2 & 163.2 & $\mathbf{2 4 . 6}$ \\
\hline $\begin{array}{l}\text { Food processing and } \\
\text { related trades workers }\end{array}$ & 160.5 & 150.4 & 144.6 & 141.7 & 136.5 & 131.4 & 127.1 & 121.0 & 115.9 & $\mathbf{2 7 . 8}$ \\
\hline $\begin{array}{l}\text { Subsistence famers, } \\
\text { fishers, hunters and } \\
\text { gatherers }\end{array}$ & 234.0 & 221.9 & 212.6 & 205.1 & 197.6 & 190.4 & 183.4 & 175.6 & 168.2 & $\mathbf{2 8 . 1}$ \\
\hline $\begin{array}{l}\text { Garment and related } \\
\text { trades workers; Other craft } \\
\text { and related workers }\end{array}$ & 202.8 & 181.8 & 166.6 & 154.7 & 152.5 & 150.3 & 148.8 & 145.1 & 142.6 & $\mathbf{2 9 . 7}$ \\
\hline Printing trades workers & 41.6 & 37.1 & 33.8 & 31.2 & 30.7 & 30.3 & 30.0 & 29.2 & 28.7 & $\mathbf{3 1 . 0}$ \\
\hline $\begin{array}{l}\text { Mixed crop and animal } \\
\text { producers }\end{array}$ & 1051.1 & 991.4 & 944.8 & 906.2 & 868.0 & 830.9 & 795.7 & 756.7 & $\mathbf{7 2 0 . 3}$ & $\mathbf{3 1 . 5}$ \\
\hline Handicraft workers & 44.3 & 41.2 & 39.4 & 38.3 & 36.6 & 34.9 & 33.5 & 31.6 & 29.9 & $\mathbf{3 2 . 4}$ \\
\hline $\begin{array}{l}\text { Painters, building } \\
\text { structure cleaners and } \\
\text { related trades workers }\end{array}$ & 104.8 & 97.4 & 92.8 & 90.0 & 85.9 & 81.8 & 78.2 & 73.6 & 69.6 & $\mathbf{3 3 . 6}$ \\
\hline
\end{tabular}

Source: forecast results. 
Changes in employment, described in Table 1 and 2, show the tendencies on the Polish labour market till 2020. However, it is important to take into account not only dynamics but also the levels of employment, as they constitute those occupational groups in which demand for labour, in absolute terms, will be biggest (Table 3) or lowest (Table 4) in 2020.

The forecast shows that Polish economy will need almost 1.4 million salespersons in 2020 to fulfil the market demand (Table 3). This is the only minor group in which number of employees exceeds 1 million. The other groups on the "top 10" list will generate perceptible smaller employment levels, with only three groups above 0.5 million: mixed crop and animal producers, administration professionals and heavy truck and bus drivers. Some of the minor groups that are listed in Table 3 are also present in the Table 1 (administration professionals, sales, marketing and public relations professionals; finance professionals), which reaffirms the conclusion that these occupational groups are of growing importance for the Polish economy. In some cases (mixed crop and animal producers; building finishers and related trades workers; domestic, hotel and office cleaners and helpers, food preparation assistants; and building frame and related trades workers) in spite of falling number of employees between 2012 and 2020, these groups should still maintain their high position as for labour demand.

\section{Table 3. 10 minor occupational groups with highest employment in 2020 (in ths)}

\begin{tabular}{|l|c|c|c|c|c|c|c|c|c|}
\hline \multirow{2}{*}{ Minor group } & \multicolumn{7}{|c|}{ Year } \\
\cline { 2 - 9 } & $\mathbf{2 0 1 2}$ & 2013 & $\mathbf{2 0 1 4}$ & 2015 & 2016 & $\mathbf{2 0 1 7}$ & $\mathbf{2 0 1 8}$ & $\mathbf{2 0 1 9}$ & $\mathbf{2 0 2 0}$ \\
\hline $\begin{array}{l}\text { Shop salespersons; Street and } \\
\text { market salespersons; Other } \\
\text { sales workers }\end{array}$ & 1302.8 & 1301.6 & 1309.2 & 1322.3 & 1332.5 & 1343.1 & 1356.1 & 1365.2 & $\mathbf{1 3 7 6 . 1}$ \\
\hline $\begin{array}{l}\text { Mixed crop and animal } \\
\text { producers }\end{array}$ & 1051.1 & 991.4 & 944.8 & 906.2 & 868.0 & 830.9 & 795.7 & 756.7 & $\mathbf{7 2 0 . 3}$ \\
\hline $\begin{array}{l}\text { Administration professionals; } \\
\begin{array}{l}\text { Sales, marketing and public } \\
\text { relations professionals }\end{array}\end{array}$ & 389.4 & 405.1 & 425.2 & 449.3 & 472.0 & 495.3 & 519.8 & 541.5 & $\mathbf{5 6 4 . 8}$ \\
\hline Heavy truck and bus drivers & 471.7 & 470.5 & 474.7 & 482.5 & 488.7 & 496.7 & 505.7 & 511.9 & $\mathbf{5 1 9 . 5}$ \\
\hline Finance professionals & 265.9 & $\mathbf{2 7 6 . 0}$ & 289.2 & 305.0 & 319.9 & 335.2 & 351.3 & 365.5 & $\mathbf{3 8 0 . 7}$ \\
\hline $\begin{array}{l}\text { Building finishers and related } \\
\text { trades workers }\end{array}$ & 397.6 & 382.2 & 377.3 & 379.5 & 375.6 & 371.7 & 369.6 & 362.0 & $\mathbf{3 5 7 . 2}$ \\
\hline $\begin{array}{l}\text { Financial and mathematical } \\
\text { associate professionals }\end{array}$ & 344.4 & 343.6 & 344.8 & 347.2 & 348.9 & 350.5 & 352.4 & 353.2 & $\mathbf{3 5 4 . 5}$ \\
\hline $\begin{array}{l}\text { Domestic, hotel and office } \\
\text { cleaners and helpers; Food } \\
\text { preparation assistants }\end{array}$ & 382.8 & 373.3 & 368.0 & 365.3 & 361.4 & 357.8 & 354.9 & 350.2 & $\mathbf{3 4 6 . 5}$ \\
\hline Protective services workers & 316.6 & 317.5 & 320.5 & 324.9 & 328.6 & 332.4 & 336.8 & $\mathbf{3 4 0 . 2}$ & $\mathbf{3 4 4 . 2}$ \\
\hline $\begin{array}{l}\text { Building frame and related } \\
\text { trades workers }\end{array}$ & 347.9 & 336.3 & 333.7 & 337.4 & 335.8 & 334.0 & 333.8 & 328.6 & $\mathbf{3 2 5 . 8}$ \\
\hline
\end{tabular}

Source: forecast results.

Finally, there are minor occupational groups which share in the total employment is small - the 10 minor groups with the lowest employment level 
(Table 4), according to the forecasts, will account only for 137.7 ths of employees in 2020 (that is only $10 \%$ of the number of shop salespersons, which is the group of the highest demand). However, it does not mean that these minor groups are insignificant for the Polish labour market. Within these 10 groups there are, for example, legislators and senior officials, who play important role in policy making and its implementation, or ship and aircraft controllers and technicians, who are responsible for security measures. Moreover, in case of veterinarians, their number is forecasted to increase by $20.3 \%$ between 2012 and 2020, while the number of telecommunications and broadcasting technicians; and nursing and midwifery associate professionals should raise by, respectively, $9.3 \%$ and $8.8 \%$.

\section{Table 4. 10 minor occupational groups with lowest employment in 2020 (in ths)}

\begin{tabular}{|c|c|c|c|c|c|c|c|c|c|}
\hline \multirow[b]{2}{*}{ Minor group } & \multicolumn{9}{|c|}{ Year } \\
\hline & 2012 & 2013 & 2014 & 2015 & 2016 & 2017 & 2018 & 2019 & 2020 \\
\hline $\begin{array}{l}\text { Telecommunications } \\
\text { and broadcasting } \\
\text { technicians }\end{array}$ & 17.0 & 17.1 & 17.3 & 17.6 & 17.8 & 18.0 & 18.3 & 18.4 & 18.6 \\
\hline $\begin{array}{l}\text { Commissioned armed forces } \\
\text { officers }\end{array}$ & 21.0 & 20.4 & 19.9 & 19.6 & 19.2 & 18.8 & 18.5 & 18.1 & 17.8 \\
\hline Sports and fitness workers & 18.7 & 18.4 & 18.2 & 18.0 & 17.9 & 17.7 & 17.5 & 17.3 & 17.2 \\
\hline $\begin{array}{l}\text { Legislators and senior } \\
\text { officials }\end{array}$ & 16.9 & 16.7 & 16.6 & 16.7 & 16.7 & 16.8 & 16.9 & 16.8 & 16.9 \\
\hline Veterinarians & 13.0 & 13.1 & 13.4 & 13.9 & 14.2 & 14.6 & 15.0 & 15.3 & 15.6 \\
\hline $\begin{array}{l}\text { Nursing and midwifery } \\
\text { associate professionals; } \\
\text { Traditional and } \\
\text { complementary medicine } \\
\text { associate professionals; } \\
\text { Veterinary technicians and } \\
\text { assistants }\end{array}$ & 11.9 & 11.9 & 12.1 & 12.2 & 12.4 & 12.5 & 12.7 & 12.8 & 12.9 \\
\hline $\begin{array}{l}\text { Travel attendants, } \\
\text { conductors and guides }\end{array}$ & 14.3 & 14.0 & 13.8 & 13.6 & 13.5 & 13.3 & 13.2 & 13.0 & 12.8 \\
\hline $\begin{array}{l}\text { Librarians, archivists and } \\
\text { curators }\end{array}$ & 12.2 & 12.1 & 12.1 & 12.2 & 12.2 & 12.2 & 12.2 & 12.2 & 12.2 \\
\hline $\begin{array}{l}\text { Ship and aircraft controllers } \\
\text { and technicians }\end{array}$ & 8.9 & 8.9 & 8.9 & 9.0 & 9.0 & 9.0 & 9.1 & 9.1 & 9.1 \\
\hline $\begin{array}{l}\text { Street vendors (excluding } \\
\text { food); Street and related } \\
\text { service workers }\end{array}$ & 4.8 & 4.7 & 4.7 & 4.7 & 4.7 & 4.7 & 4.7 & 4.6 & 4.6 \\
\hline
\end{tabular}

Source: forecast results.

\section{Conclusions}

An important element of the institutional framework of the labour market in the modern economies is a system of anticipating skills needs. Usually, such a system is focused on projecting and forecasting demand for labour by occupation and with regard to some other dimensions (i.e. industries, qualifica- 
tions, etc.). Information provided by this system is of a great importance for policy makers, and also for other labour market actors, as it helps to counteract future mismatches between qualification requirements and formal and informal qualifications acquired by individuals. In other words, the system of forecasting skills needs helps to balance the labour market in a short and medium term. The importance of such a system is confirmed by the fact that at the European Union level, CEDEFOP has been conducting for years many projects on forecasting labour demand and skills demand in the EU. At the same time, it is assumed that every EU Member State has set up its own system for forecasting labour demand.

The paper described the system of the employment forecasting that has been implemented in Poland within the framework of an EU funded project Analysis of the processes on the Polish labour market and in the area of social integration in the context of conducted economic policy, Task 2 Establishing the integrated forecasting and information system providing employment forecasts. It presented the main assumptions and elements of the system (the structure of econometric models and on-line forecasting tool) that should be fully operable till October 2014. The paper also elaborated on employment forecasts at national, regional and occupational levels. The analysis of forecasts enabled to draw some conclusions, important from the point of view of the perspectives of the Polish labour market and the labour market policy.

Firstly, employment in Poland will slightly decrease between 2012 and 2020, with rapid decline to 2014, and then continuous recovery to 2018 .

Secondly, there will be large differences between regions in employment dynamics - in Dolnoslaskie and Pomorskie regions employment will raise by 4.2\%, while in Lubuskie and Podlaskie region will fall by, respectively, $13.5 \%$ and $13.1 \%$.

Thirdly, forecasts reaffirm changes in the employment structure (sectoral as well as occupational). This confirms the research hypothesis defined in this paper - decreasing demand for workers in the agriculture sector will be complemented by increasing demand for workers in the service sector. The fastest growing occupational groups will be these in which high skills are required. At the same time, demand for low-skilled workers will continuously decline. It means, that changes on the Polish labour market should follow development paths similar to these in highly developed economies.

\section{References}

Acemoglu D., Autor D. (2011), Skills, Tasks and Technologies: Implications for Employment and Earning [in] O. Ashenfelter, D. Card (eds), Handbook of Labour Economics, Vol. 4B, Elsevier, Amsterdam, pp. 1043-1171. 
Arendt E., Ulrichs M. (eds) (2012), Best practices in forecasting labour demand in Europe, Instytut Pracy i Spraw Socjalnych, Warsaw.

Bukowski M. (ed.) (2010), Employment in Poland 2008. Work over the life course, Human Resources Development Centre, Warsaw.

Capellen A., Gjefsen H., Gjelsvik M., Holm I., Stolen N.M. (2013), Forecasting demand and supply of labour by education, Statistics Norway, Oslo.

Cörvers F., Dupuy A. (2010), Estimating Employment Dynamics across Occupations and Sectors of Industries, „Journal of Macroeconomics”, vol. 32, issue 1, pp. 17-27.

De arbeidsmarkt naar opleiding en beroep tot 2016 (2011), Researchcentrum voor Onderwijs en Arbeidsmarkt, Maastricht University, School of Business and Economics, Maastricht.

Future skills needs in Europe: medium-term forecast. Background technical report (2009), CEDEFOP, Luxembourg: Publications Office of the European Union.

Future skills supply and demand in Europe. Forecast 2012 (2012), CEDEFOP, Luxembourg: Publications Office of the European Union.

Heijke H. (ed.) (1994), Forecasting the Labour Market by Occupation and Education, Springer Science+Business Media, New York.

Helmrich R., Zika G. (eds) (2010), Beruf und Arbeit in der Zukunft - BIBB-IABModellrechnungen zu den Entwicklungen in den Berufsfeldern und Qualifikationen bis 2025, W. Bertelsmann Verlag, Bielefeld.

Hyndman R. J., Booth H. (2008), Stochastic population forecasts using functional data models for mortality, fertility and migration, "International Journal of Forecasting", vol. 24, Issue 3, pp. 323-342.

Kryńska E. (2007), Podstawy konstrukcji modelu systemu zmniejszania niedostosowań strukturalnych podaży pracy $i$ popytu na prace $w$ województwie mazowieckim [in] E. Kryńska (ed.), Regionalny system koordynacji rynku pracy województwa mazowieckiego PRACA-ZATRUDNIENIE-SZKOLENIE. Syntezy wyników badań i rekomendacje, Tom II, Instytut Organizacji i Zarządzania w Przemyśle i Instytut Pracy i Spraw Socjalnych, Warszawa.

Kwiatkowski E., Kwiatkowska W., Gajdos A. (2011), Stworzenie koncepcji modeli prognoz zatrudnienia wedtug zawodów dla wybranego województwa, mimeo, Instytut Pracy i Spraw Socjalnych, Warszawa.

Neugart M., Schomann K. (eds) (2002), Forecasting labour markets in OECD countries. Measuring and tackling mismatches, Edward Elgar, Cheltenham, Northampton.

New Skills for New Jobs. Anticipating and matching labour market and skills needs, Communication from the Commission, COM(2008) 868, 16 December 2008. 
Prognoza ludności na lata 2008-2035 (2009), Główny Urząd Statystyczny, Warszawa.

Fox R., Cornerford B. (2008), Estimating replacement demand: lessons from Ireland, „International Journal of Manpower”, vol. 29, Issue 4, pp. 348-361.

Wilson R. (2013), Skills anticipation - The future of work and education, „International Journal of Educational Research”, vol. 61, pp. 101-110. 